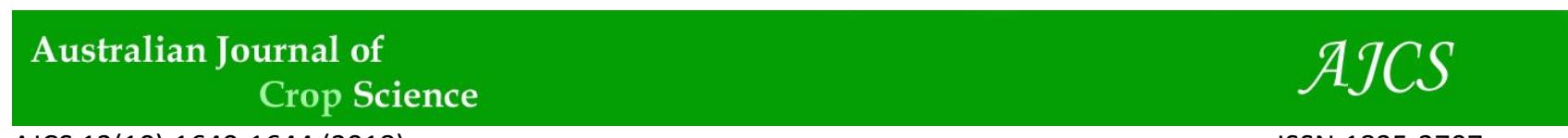

AJCS 12(10):1640-1644 (2018)

ISSN:1835-2707

doi: 10.21475/ajcs.18.12.10.pne1341

\title{
Analysis of the non-timber forest products market in the Brazilian Amazon
}

\author{
Humberto Angelo ${ }^{1}$, Rafael de A. Calderon ${ }^{2}$, Alexandre N. de Almeida ${ }^{1}$, Maristela F. de Paula ${ }^{3}$, Milton \\ Meira $^{1}$, Eder P. Miguel ${ }^{1}$, Pedro G. A. Vasconcelos* ${ }^{1}$
}

${ }^{1}$ Department of Forestry Engeneering, University of Brasilia (UnB), DF, Brazil.

${ }^{2}$ Federal University of Acre (UFAC), AC, Brazil

${ }^{3}$ State University of West Centre (UNICENTRO), PR, Brazil

*Corresponding author: pedroguilherme.av@gmail.com

\begin{abstract}
The non-timber forest products (NTFP) market in the Brazilian Amazon plays a key role in social, economic, and forest sustainability. Are considered as belonging to the NTFP designation all those products extracted from the forest which is not wood, such as leaves, fruits, fibers, seeds, oils, resins, gums and others. This market has been poorly explored in the country. This study discusses the market for NTFP in the Amazon region. This study aims to measure the response of the extractive supply of NTFP to price changes during the period 1973-2011. We used econometric tools for the analysis, where the supply and demand equations were specified and adjusted by the Ordinary Least Squares method. The price response was measured by the estimation of two logarithmic models for each of the products. Simultaneous models of supply and demand for NTFPs were developed and used to explain the behavior of this market. The results showed low price elasticity for the supply, which means that the quantity produced showed a low response to price. Our findings imply that the NTFP market in the Amazon shows economic potential, although it requires investments in regional infrastructure for production, training, and organization of extractive communities, and marketing support. Our results have important implications for policymakers to formulate effective subsidy policies to encourage the commercial production of NTFPs and to strengthen the NTFP market in the region.
\end{abstract}

Keywords: sustainability, economics, Amazon rainforest.

Introduction

This study analyzes the market for non-timber forest products (NTFP) in the Brazilian Amazon, Myers (1988) considers that non-timber products are those products which can be harvested from the forest, which are not wood or wood for fuel purposes such as fruits, bark, resins and oils. NTFP plays an important role in the economic, social, and political formation of the Amazon region (Aguiar et al., 2017). Extractivism is considered important by the Brazilian government and this has resulted in the creation of numerous conservation units of sustainable use such as Extractive Reserves, Sustainable Development Reserves, and National Forests (see law number 9.985 of July 18, 2000). However, this extractive activity remains outdated, economically unsustainable, and undeveloped. The extraction of NTFP has attracted the attention of the society, public managers, and policymakers, especially owing to the potential income generation and environmental conservation. In the last two decades, various laws, policies, plans, and programs have been implemented to stimulate and support the extractivism of NTFP and its markets (Afonso et al., 2014). Small cities have increased their population and income because of a resource base provided by their proximity to forests and access to an ecosystem that consists of not only timber but also NTFP (Nadkarni, 2017). Most traditional and emerging companies in this sector tend to be small-scale and family-owned; and there is a large untapped potential for NTFPs to support rural development and increase incomes of landowners and rural enterprises (Ludvig et al., 2016). NTFPs have been gaining prominence among researchers as an alternative tool for income generation (Shankar et al., 1998; Afonso and Angelo, 2009; Almeida et al., 2009; Guerra et al. 2009; Nogueira et al., 2009; Nogueira and Santana, 2016). These studies have immensely contributed to the understanding of the NTFP market (Homma, 2008, 2012; Angelo et al., 2013). All these studies have reached a consensus that NTFP market is a complex activity and with a lack of market studies. If NTFPs respond favorably to prices, market policies that contribute to the development of extractive communities in the region, public policies, and other instruments are recommended. This study aims to contribute to the NTFP literature through a quantitative approach. Thus, the objectives of this study are two-fold: a) To measure the response of the NTFP extraction offer to the price; and b) to provide subsidies to public managers in the scope of public policy formulation for the NTFP market in the Brazilian Amazon.

Results

Model 1

The price variable presented significant coefficients at $5 \%$ for palm heart, copaíba oil, and Brazil nuts (Table 1). For the 
coefficients, we expected them to be positive for the price variable and undefined a priori for the trend variable. However, the coefficients of the price variable showed a negative sign for rubber, palm heart, and babassu almonds. The açaí was not included in the table because, for this product, the estimated coefficients were not significant at $10 \%$. The low values presented by the coefficients of determination of several products and the low coefficients presented by the price variable, usually less significant than those presented by the trend variable, suggest that the model can still be improved by the incorporation of other explanatory variables.

The Durbin-Watson " $d$ " statistic did not indicate the presence of first-order positive serial autocorrelation in the residues of any of the products. The most significant variable, the trend, was significant at $1 \%$ for all products.

\section{Model 2}

To complement the model, we introduced as an explanatory variable, the dependent variable, lagged in a period (Qt-1) (Pastore, 1973). The F test rejects the joint hypothesis that all coefficients are simultaneously equal to zero at a significance level of less than $1 \%$ for all products.

The coefficients of the price variable were positive for most products, as expected, for Model 2 (Table 2), including for rubber, whose coefficient estimated by Model 1 was negative. For palm heart, the coefficient of the price variable remained negative and significant.

The Durbin's " $h$ " statistic, with values between -1.96 and 1.96, indicates with $95 \%$ probability that there is no evidence of serial autocorrelation of the residues in any of the estimated models. The $\mathrm{F}$ test rejects the joint hypothesis that all coefficients are simultaneously zero at a significance level of less than $1 \%$ for all products.

The low values estimated for the coefficients of the price variable indicate a supply situation that is highly inelastic to the price.

\section{Discussion}

Falesi et al. (2011) estimated the coefficient of price elasticity of supply for extractive açaí as 0.114 in Pará state, Brazil, which is consistent with this study. On the other hand, Sant'Anna and Nogueira (2010) estimated the value as 0.94; however, these authors used the total production of açaí by adding the extractive product to the cultivated one. This reinforces and provides evidence that only the extractive supply is inelastic. The trend variable showed a significant coefficient of $10 \%$ for copaiba oil, palm heart, and Brazil nuts. The lagged variable Qt-1 had a positive coefficient in all cases, except for copaiba oil. Rubber, açaí, and babassu almonds presented coefficients, significant at $10 \%$, of $0.86,0.65$ and 0.78 , respectively. There is a strong positive relation between the production of the current year and that of the previous year (Sant'Anna and Nogueira, 2010). The coefficient of the price variable is positive and significant at $10 \%$ for Brazil nuts and copaiba oil, while being negative and significant for palm heart. We observed that the most consistent results occurred for copaiba oil, with coefficients ranging from 0.36 to 0.37 , and always being significant. Although the result is in line with our prediction, the magnitude of response was low, which explains the inelasticity of supply to price, it presented a low magnitude, which describes an inelastic supply of the price. If there is a
$10 \%$ change in the price of copaiba oil, the quantity supplied will change in the same direction, approximately $3.6 \%$. The studied products presented coefficients very close to zero. Rubber and palm heart had negative coefficients. Specifically, palm heart had negative and significant coefficients of -0.61 and -0.51 indicating a reduction in supply between $6 \%$ and $5 \%$ for a $10 \%$ increase in prices. This result describes the inability of supply to respond to prices. For each year, we find that the higher the supply, the lower the price, and vice versa. This scenario was caused both by the scarcity of the product in some producing regions and by the fight against the illegal extraction of palm heart. In general, the products showed very little sensitivity to price changes. Using the Generalized Moments Method, the price elasticity of supply for açaí was 0.94 (Sant'Anna and Nogueira, 2010). However, Sant'Anna and Nogueira 2010 analyzed the global supply in the state considering extractive production and crop production. The results corroborated with Lopes and Santana (2005), who estimated the price elasticity of açaí supply in the state of Pará as 1.003, also from the joint production of extractivism and cultivation. Falesi et al. (2011) show a price elasticity of supply of 0.11 for extractive fruits in the state of Pará, characterizing the market as inelastic, similar to our study. Considering that the market does not differentiate extractive production from crop production, as is the case with the açai market, the equilibrium price observed in the market is the result of the interaction between demand and the joint supply of extractivism and cultivation. Thus, the price elasticity of supply of this study, as found by Falesi et al. (2011), cannot be considered representative of the global market, but of the extractive market, the supply of extractive products seems to be inelastic because not have the same capacity to respond to price stimuli of the cultivated products.

NTFP's commercial production, on a community basis, requires government funding, provision of credit or microcredit, and the need for training and capacity building of extractive communities (Guerra et al., 2009). The lack of adequate technologies for NTFP production, conditions of access to transportation and information in producing regions, local cultural characteristics, alternative options for income generation, and subsistence of producers may be related to the low price elasticity of supply found in our study.

In poorly developed areas, shortcomings in transport and communications facilities may restrain a smoother functioning of the factor inputs market, and only if the economic stimulus persists for a longer period will they lead to a more sensitive reallocation of the sensitive factors (Pastore 1973).

The mobilization of factors of production in the field is more rigid than in other sectors of the economy. These results point to the need for durable public policies for the promotion of NTFP production. They also point to the need for policies to support the organization and empowerment of communities that can benefit from NTFP production and the subsequent manufacture of finished products. The inability of the supply of extractive products to respond to the price, that is, an inelastic price offer, is attributable to the fact that the supply has reached the productive limit of the environment (Homma, 1993, 2012). It is possible to increase supply only by adding new areas to production. Increased public investment in the areas of infrastructure, improved market access, and provision of credit for production and marketing will probably have a positive effect on NTFP production in the Brazilian Amazon, although this is possible only in the medium or long run" be 
Table 1. Response of the quantity of NTFP offered at the price in the period from 1973 to 2011 and of the model 1. Where: $\beta$ : are the parameters of the model; F: Calculated value of the F statistic; $d$ : calculated value for Durbin-Watson " $d$ " statistic; ns: there is no indication of serial correlation of the residues.

\begin{tabular}{|c|c|c|c|c|c|c|c|}
\hline Product & & $\beta_{0}$ & $\beta_{1}$ & $\beta_{2}$ & $\mathrm{R}^{2}$ & $\mathrm{~d}$ & $\mathrm{~F}$ \\
\hline & Coefficients & 9.69 & 0.15 & -0.02 & 0.39 & $1.55^{\mathrm{ns}}$ & 10.11 \\
\hline \multirow[t]{3}{*}{ Brazil nuts } & $t$ Student & & 2.12 & -3.29 & & & \\
\hline & Significance & & 0.04 & 0.00 & & & $>0.001$ \\
\hline & Coefficients & 11.98 & -0.07 & -0.09 & 0.36 & $1.80^{\text {ns }}$ & 8.97 \\
\hline \multirow[t]{3}{*}{ Rubber } & $t$ Student & & -0.59 & -4.21 & & & \\
\hline & Significance & & 0.56 & 0.00 & & & $>0.001$ \\
\hline & Coefficients & 16.06 & -0.61 & -0.08 & 0.64 & $1.50^{\mathrm{ns}}$ & 28.22 \\
\hline \multirow[t]{3}{*}{ Palm heart } & $t$ Student & & -2.51 & -4.79 & & & \\
\hline & Significance & & 0.02 & 0.00 & & & $>0.001$ \\
\hline & Coefficients & -0.22 & 0.36 & 0.11 & 0.80 & $1.91^{\mathrm{ns}}$ & 61.66 \\
\hline \multirow[t]{3}{*}{ Copaíba oil } & $t$ Student & & 2.68 & 11.10 & & & \\
\hline & Significance & & 0.01 & 0.00 & & & $>0.001$ \\
\hline & Coefficients & 12.57 & -0.00 & -0.03 & 0.46 & $1.52^{\text {ns }}$ & 13.44 \\
\hline \multirow[t]{2}{*}{ Babassu almonds } & $t$ Student & & -0.04 & -5.09 & & & \\
\hline & Significance & & 0.97 & 0.00 & & & $>0.001$ \\
\hline
\end{tabular}

Table 2. Response of the quantity of NTFP offered at the price in the period from 1973 to 2011 and of the model 2. Where: $\beta$ : are the parameters of the model; F: Calculated value of the F statistic; $d$ : calculated value for Durbin-Watson " $d$ " statistic; ns: there is no indication of serial correlation of the residues.

\begin{tabular}{|c|c|c|c|c|c|c|c|}
\hline Produto & & $\beta_{0}$ & $\beta_{1}$ & $\beta_{2}$ & $\beta_{3}$ & $\mathrm{R}^{2}$ & $\mathrm{~F}$ \\
\hline & Coefficients & 3.17 & 0.13 & 0.65 & 0.00 & 0.90 & 85.63 \\
\hline \multirow[t]{3}{*}{ Açai fruit } & $t$ Student & & 1.59 & 11.05 & 1.07 & & \\
\hline & Significance & & 0.12 & 0.00 & 0.30 & h 1.35 & $>0.00$ \\
\hline & Coefficients & 8.75 & 0.13 & 0.10 & -0.01 & 0.42 & 7.51 \\
\hline \multirow[t]{3}{*}{ Brazil nuts } & $t$ Student & & 2.03 & 0.55 & -2.57 & & \\
\hline & Significance & & 0.05 & 0.58 & 0.02 & h 0.16 & 0.00 \\
\hline & Coefficients & 1.31 & 0.02 & 0.86 & -0.01 & 0.94 & 154.26 \\
\hline \multirow[t]{3}{*}{ Rubber } & $t$ Student & & 0.24 & 9.35 & -1.13 & & \\
\hline & Significance & & 0.81 & 0.00 & 0.27 & h 0.45 & $>0.00$ \\
\hline & Coefficients & 13.01 & -0.51 & 0.20 & -0.06 & 0.72 & 26.54 \\
\hline \multirow[t]{3}{*}{ Palm heart } & $t$ Student & & -1.90 & 1.11 & -3.62 & & \\
\hline & Significance & & 0.07 & 0.27 & 0.00 & h 0.78 & $>0.00$ \\
\hline & Coefficients & -0.07 & 0.37 & -0.08 & 0.12 & 0.77 & 32.88 \\
\hline \multirow[t]{3}{*}{ Copaíba oil } & $t$ Student & & 2.25 & -0.43 & 4.75 & & \\
\hline & Significance & & 0.03 & 0.67 & 0.00 & h -0.86 & 0.00 \\
\hline & Coefficients & 2.35 & 0.05 & 0.78 & -0.01 & 0.93 & 136.71 \\
\hline \multirow[t]{2}{*}{ Babassu almonds } & $t$ Student & & 1.67 & 6.71 & -1.16 & & \\
\hline & Significance & & 0.11 & 0.00 & 0.26 & h 0.21 & 0.00 \\
\hline
\end{tabular}

more appropriate. Minimum price policies for the extractive product can guarantee remuneration of the producing families without causing major changes in the quantities extracted from the forest.

\section{Materials and Methods}

\section{Data collected}

In this study, we analyzed data on the production and commercialization of six Brazilian NTFPs, predominantly Amazonian: açaí, babassu almonds, Brazil nut, palm heart, rubber, and copaiba oil. From the temporal point of view, were carried out data for the period from 1973 to 2011 to the analyses of growth rate, response to prices, and supply and demand for NTFPs.

We primarily use data contained in the Brazilian Statistical Yearbooks published by the Brazilian Institute of Geography and Statistics (IBGE). We collected data regarding the quantities produced and NTFP production value derived exclusively from extractive activities. Since the Statistical Yearbooks contain information on the values and quantities of NTFP produced, the average value or average price of the product is calculated by dividing the value produced by the quantity produced. We use IBGE data because is an official institution in Brazil responsible for the collection and maintenance of historical series referring to the most diverse sectors of the economy, as well as census data. Albeit there are limitations in some data series, including annual rather than monthly frequency for many data, especially for those of regional or national scope, such as those used in this study, on NTFP production in the Amazon, the series maintained by IBGE are the only source available.

\section{Data treatment}

We convert all monetary values into Reais before their deflation (Castanheira, 2008; Hoffmann et al., 2012). In the update of the values, we used an inflation index. In this study, we opted to use the Wholesale Price Index (IPA-DI) maintained by the Getúlio Vargas Foundation, see http://portalibre.fgv.br.

\section{Econometric analysis}

During the 1960s, it was widely believed that one of the problems of non-technological agriculture in less developed 
countries was the low response of agricultural production to prices. This would lead to the lag in the adjustment between the quantity demanded and supplied of agricultural products (Pastore, 1973). The theoretical model adopted by Pastore (1973) was based on the study of Nerlove (1958). This model is most widely used in applied econometrics (Diebold and Lamb, 1997; Thiele, 2000). Prior to this model, the Nerlove model was the most influential model of agricultural supply analysis (Mamingi, 1996), and is still being used widely (Yu et al., 2012). Unlike the dominant thinking in the 1970s, several Brazilian agricultural products responded positively to prices (Pastore, 1973). In his study, this author compared the results of several models, using four different methods: Ordinary Least Squares (OLS), Two-Stage Least Squares (2-SLS), Three-Stage Least Squares (3-LSL), and two-stage method proposed by Keneth Wallis. From Pastore (1973), two of the most promising models were selected for an adjustment test for the six NTFPs selected in this study. Considering that the extractive activity would share the same characteristics that would lead to the lack of adjustment between demand and supply, resulting in low price elasticity of supply, it was decided to test the adjustment of extractive NTFPs in the Amazon to the Nerlovian models proposed by Pastore (1973).

The models tested, both in logarithmic form, consider the following variables:

$Q$ is the amount of NTFP being analyzed:

Pt-1 is the price of the product in the previous year (t-1);

Qt-1 is the amount produced in the previous year (t-1);

$\mathrm{T}$ is a trend variable, always in arithmetic form: $1,2,3,4, \ldots, \mathrm{n}$; $\varepsilon$ is random error

In is the natural logarithm.

Model 1: $\ln (Q)=\alpha+\beta 1 * \ln (P t-1)+\beta 2 * T+\varepsilon$

Model 2: $\ln (Q)=\alpha+\beta 1 * \ln (P t-1)+\beta 2 * \ln (Q t-1)+\beta 3 * T+\varepsilon$

The selected models are quite simple when compared to those available in the forest products market literature. These include in the supply equation, besides the price of the product itself, variables such as the price of labor and the price of capital (Soares et al., 2009); exchange rate, minimum wage, interest rate, and trend (Soares et al., 2004); exchange rate, domestic price index, installed industrial capacity and trend (Brasil et al., 2003); and investment in the sector and productivity (Angelo et al., 2009).

The two models tested include the price variable in the lagged form (Pt-1), due to the supposed theoretical discrepancy between the change in market price and its effect on producers' behavior. One of the models includes, among the explanatory variables, the dependent variable (Qt-1), due to a theoretical rigidity in relation to the type of product that he extracts and markets. To analyze the effect of non-discriminated variables, such as technological advance, advancement in regional infrastructure, increase of consumer markets, and even the development of the processing industry, which consumes several of our NTFPs, we included the trend variable in all models, in the arithmetical form (Pastore, 1973). We used the data of the quantities sold and the production value for 1975-2011 for all products. Furthermore, dividing the accumulated value by the quantity produced, in tons, we obtained the average price paid per ton of each NTFP.

In order to verify the existence of simultaneity between the variable quantity $(Q)$ and the variable price, lagged in one period (Pt-1), we used the Hausman specification test
(Wooldridge, 2012). The test did not confirm the existence of simultaneity between the variables price and quantity at $5 \%$ level of significance. If there is no concurrency problem, the OLS estimators will be consistent and efficient (Wooldridge, 2012), which we applied in this study using the IBM SPSS Statistics version 19 software.

For the verification of the existence of first-order positive serial autocorrelation in the residues the Durbin-Watson " $d$ " test for Model 1 and the Durbin " $h$ " test for Model 2 were used, as described by Wooldridge (2010) and Greene (2007).

Evaluation of models

The equations of models 1 and 2 were estimated by the OLS method (Gujarati, 2011). For both the models, the hypothesis of simultaneity was tested using the Hausman test (Gujarati, 2011), which did not confirm the presence of simultaneity between the variables, price and quantity.

The presence of multicollinearity was assessed by the tolerance values and the Inflation Factor of Variance (IFV) (Gujarati, 2011), although there are no strict limits to this analysis. If the values calculated for tolerance are not below 0.1 and the IFV are not higher than 10.00, it is considered that the model does not present a problem of multicollinearity among its explanatory variables. We also tested the presence of heteroscedasticity in models 1 and 2 by applying the White test (Gujarati, 2011), and found that the models did not present heteroscedasticity at $1 \%$ probability. We used the Durbin-Watson " $d$ " test to evaluate the presence of serial autocorrelation of the residues in Model 1 and the Durbin " $\mathrm{h}$ " test for Model 2. The Durbin's " $h$ " statistic, with values ranging between -1.96 and 1.96 , indicates with $95 \%$ probability that there is no evidence of serial autocorrelation of the residues in any of the estimated models. We also used the Cochrane-Orcutt iterative technique to estimate the models as a way of correcting autocorrelation.

The adjustment of the parameters of the models to the data was analyzed by the coefficients of determination "R2." The "F" statistics was used for assessing the global significance of the regression coefficients and the " $\mathrm{t}$ " test to assess the significance of the partial coefficients. In this study, we adopted a minimum level of significance to consider any significant statistic at $10 \%$.

\section{Conclusion}

In the period from 1973 to 2011, each of the NTFPs analyzed in this work presented its own dynamics, both in terms of price and quantity, which indicates the need for public policies that consider the specificities of each product, market, and producing region. The modernization of the extractive production and elimination of intermediaries are imperative for the sector. Currently, the diversification of government production and support to commercialization are also indispensable. If these policies are not implemented, and the ongoing initiatives are not maintained, the NTFP extractivism in the Amazon will probably remain a subsistence activity for poor families, stimulating the rural exodus.The minimum price policy for extractive NTFPs is important in guaranteeing income for extractive families. Public investment in the areas of infrastructure, improved market access and provision of credit for the production and commercialization of extractive NTFPs will have a positive effect on the Brazilian production of NTFPs, although this is possible only in the medium or long run. 


\section{Acknowledgements}

The authors are thankful for the support of the University of Brasilia and the National Council for Scientific and Technological Development (CNPq).

\section{References}

Afonso SR, Angelo H (2009) Market of non-wood forest products from Brazilian Savanna. Ciência Florestal. 19: 315-326.

Afonso SR, Angelo H, Almeida AN (2014) Characterization of Pequi production from Japonvar, MG. Floresta, 45: 49.

Aguiar, GP, Silva JCGL, Frega JR, Santana LF, Valerius J (2017) The Use of Constant Market Share (CMS) Model to assess Brazil nut market competitiveness. J Agric Sci. 9: 174.

Almeida AN, Bittencourt AM, Santos AJ, Eisfeld CDL, Souza VS (2009) Production and price evolution of the main extractive non timber forest products in Brazil. Cerne. 15: 282-287.

Angelo H, Almeida AN, Calderon RA, Pompermayer RS, Souza ÁN (2013) Determinants of the Brazil nut price (Bertholletia excelsa) on the domestic market. Scientia Forestalis. 41: 195-203.

Angelo H, Almeida AN, Serrano ALM (2009) Determinants of Brazil's demand of pulpwood. Scientia Forestalis. 37: 491-498.

Brasil AA, Angelo H, Silva JCEG, Lacowick PG (2003) Substitution in the Brazilian wood-based panels exports. Floresta e Ambiente. 10: 1-10.

Castanheira NP (2008). Métodos Quantitativos. Curitiba: Ibpex. Diebold FX, Lamb RL (1997) Why are estimates of agricultural supply response so variable? J Econometrics. 76: 357-373.

Falesi LA, Santana AC, Homma AKO, Gomes SC (2011) Evolution and interaction between fruit production and price in the State of Pará. Revista de Ciências Agrárias. 1: 69-77.

Greene WH (2007) Econometric Analysis, 6th ed. New York: Pearson Prentice Hall.

Guerra FGPQ, Santos AJ, Sanquetta CR, Bittencourt AM, Almeida AN (2009) Quantification and valuation of non wood forest products. Floresta. 39: 431-439.

Gujarati DN (2011) Econometria Básica, 5th ed. São Paulo: Amgh Editora.

Hoffmann WA, Geiger EL, Gotsch SG, Rossatto DR, Silva LCR, Lau OL, Haridasan M, Franco AC (2012) Ecological thresholds at the savanna-forest boundary: how plant traits, resources and fire govern the distribution of tropical biomes. Ecology Letters. 15: 759-768.

Homma AKO (1993) Extrativismo Vegetal Na Amazônia: Limites E Oportunidades. Empresa Brasileira de Pesquisa Agropecuária. Brasília: Centro De Pesquisa Agroflorestal da Amazônia Oriental.

Homma AKO (2008) Extrativismo, Biodiversidade E Biopirataria Na Amazônia. Brasilia: Embrapa Informação Tecnológica.

Homma AKO (2012). Plant extractivism or plantation: what is the best option for the Amazon? Estudos Avançados. 26: 167-186.
Lopes MLB, Santana AC (2005) O mercado do fruto do Açaizeiro (Euterpe Oleracea Mart.) no estado do Pará. In Economia da Amazônia nos anos 90 (Ed D. Carvalho), pp. 65-84. Belém: Universidade da Amazônia.

Ludvig A, Tahvanainen V, Dickson A, Evard C, Kurttila M, Cosovic M, Chapman E, Wilding M, Weiss G (2016) The practice of entrepreneurship in the non-wood forest products sector: Support for innovation on private forest land. Forest Policy Economics. 66: 31-37.

Mamingi N (1996) How Prices and Macroeconomic Policies Affect Agricultural Supply and the Environment, Policy Res. Washington: The World Bank.

Myers N (1988) Tropical Forests: Much More Than Stocks of Wood. Journal of Tropical Ecology, Vol. 4, No. 2 (May): 209-221.

Nadkarni M (2017) Non-timber Forest Products and Small Town Economies. In Subaltern Urbanisation in India. Exploring Urban Change in South Asia (Eds E. Denis \& M. Zérah) New Delhi Springer: 601-614.

Nerlove M (1958) Distributed lags and estimation of long-run supply and demand elasticities: theoretical considerations. Journal of Farm Economics. 40: 301-311.

Nogueira JM, Nascimento Junior A, Bastos L (2009) Extractive activities as alternatives to income generation: from the environmentalism dream to the market research reality. Revista Ciência Adminstração. 15: 85-104.

Nogueira AKM, Santana AC (2016) Benefícios socioeconômicos da adoção de novas tecnologias no cultivo do açaí no Estado do Pará. Revista Ceres. 63: 1-7.

Pastore AC (1973) A Resposta Da Produção Agrícola Aos Preços No Brasil. São Paulo: APEC.

Sant'anna AC, Nogueira JM (2010) Valoração Econômica dos Serviços Ambientais das Florestas Nacionais. Revista de Administração e Negócios da Amazônia. 2: 82-108.

Shankar U, Hegde R, Bawa KS (1998) Extraction of non-timber forest products in the forests of Biligiri Rangan Hills, India. 6 . Fuel wood pressure and management options. Economic Botany. 52: 320-336.

Soares NS, Silva ML, Fontes AA (2004) Econometric analysis of the wood charcoal Brazilian market in the period from 1974 to 2000. Scientia Forestalis. 84-93.

Soares NS, Silva ML, Valverde SR, Lima JE, Souza UR (2009) Analysis of the wood pulp Brazilian market, 1969 - 2005. Revista Árvore. 33: 563-573.

Thiele R (2000) Estimating the Aggregate Agricultural Supply Response: A Survey of Techniques and Results for Developing Countries. Kiel Working Paper, 1016: 1-25.

Wooldridge JM (2012) Introduction of Econometric: Approach Modern, 5th ed. Cincinnati, OH - USA: South-Western College Pub.

Yu B, Liu F, You L (2012) Dynamic agricultural supply response under economic transformation: A case study of henan, China. American Journal of Agricultural Economics. 94: 370-376. 